\title{
Labour Law on the Edge: Neoliberal Decline or Regeneration?
}

\section{Introductory Remarks}

$Y_{\mathrm{n}}$ the reflections that follow I intend to ponder on the processes of change that have profoundly altered labour law in the era of globalisation, and look set to continue to do so in the near future, generating manifold uncertainties about the future of the employment contract.

More specifically, I intend to proceed as follows. First I wish to retrace the features of the employment contract in its traditional form, as it emerged in the glorious years of the rise of this discipline $(\S 2)$.

I shall then briefly examine the factors - which are well illustrated in literature and do not need to be summed up here - that have led to the demise of this construct, triggering a process of change at once complex and uncertain (§3).

Consequently, I shall examine the two principal interpretative schemes used to account for this change, attempting to identify possible developments.

The first argues that, regardless of the differences in the individual institutional contexts, the evolution of labour law systems took place within a prevailing neoliberal orientation that resulted in an undermining of the bases of the European social model, to which particular attention will be paid (§ 4$)$.

The second scheme - the one that has been officially adopted by the organs of the European Union - identifies the endurance and, at the same time, the adaptation of the European Social Model in the notion of "flexicurity" (§5). However the numerous ambivalences of this notion, in terms of both concept and policy, will also be pointed out.

The reflection will be rounded off with some concluding remarks $(\S 6)$. I will ask, namely, if flexicurity alone can represent a satisfying perspective

* Full Professor of Labour Law at the Department of Legal Sciences, University of Florence. 
for a labour law under worldwide attack or if - as I believe - further theoretical work needs to be done to integrate flexicurity within a broader perspective characterised by a renewal of the foundations and the methods of the discipline. I will also hint, albeit at a very general level, at the direction which this research could take in order to point - hopefully - to a possible regeneration of labour law.

\section{The Employment Contract the Way it Used to Be}

The employment contract, as conceived in the main systems of labour law, emerged from a specific historic contingency around the middle of the last century, when changes in economic and social organisation came together with the strong regulatory power of the Nation-State to foster the standardisation and stabilisation of the employment relationships ${ }^{1}$.

Leaving its detailed legal content aside, this employment contract was constructed on the basis of a series of implicit pacts.

The first and fundamental compromise was that whereby the worker set his working energy at disposal, and hence accepted being subordinated to the employer, allowing the latter to cut transaction costs in exchange for a promise of protection and relative stabilisation of the employment relationship.

This stabilisation concerned the way the work was performed (with regular and predictable working hours, defined restrictions on the managerial power of the employer, rights for suspension from work in the case of sickness, maternity etc.), and even more importantly the very existence of the employment relationship (with restrictions on the power of dismissal, which even implied, in many systems, the right to be reinstated in the job in the case of illegitimate dismissal). Therefore it was a stabilisation imposed by legislation, but also to a degree unilaterally promised by the employers, since it fitted well with the Fordist mode of production. Flexible contracts, such as the fixed-term contract, did exist but played a secondary role. Production was essentially internalised and localised in the national dimension.

Rounding off the picture was the role of the unions, which from both outside and inside the enterprise (here too through worker representation bodies) acted as the guarantor of the overall equilibrium of the employment relationships.

${ }^{1}$ See S. Deakin, The Many Futures of the Contract of Employment, [in:] J. Conaghan, R.M. Fischl, K. Klare (eds), Labour Law in an Era of Globalization, Transformative Practices and Possibilities, Oxford University Press, Oxford 2002, p. 194-195. 
But the terms of the implicit pact were not limited to those mentioned above. As has frequently been pointed out, the employment contract was supported from outside by the presence of a "third agent", namely the State. Indeed, through policies of a Keynesian stamp the State supplied the resources necessary to mutualise many of the risks incumbent on both the employees and the employers themselves.

In sum, the development of labour law was seen as a way of redressing inequalities of bargaining power inherent in the employment relationship and implementing a redistribution leading to the principle of equality, in contrast with the liberal concept of economic and social life ${ }^{2}$. The divide between labour law and liberalism has never been as great as in this particular historic phase.

This regulation was driven by a strong normative impetus, triggered by a social philosophy that was the typical expression of the spirit of the time: the idea of completing the democratic process not only in the field of political and electoral reforms, but also in social terms, under the banner of a new and comprehensive conception of social citizenship ${ }^{3}$.

In this situation, the epistemological knowledge of the labour lawyer developed in ways which we could a posteriori deem fairly simple, in other words by laying the foundations of labour law almost exclusively in the world of values, and therefore essentially conceiving the discipline as a factor that curbed economic activity for the sake of social and more broadly humanistic values.

In numerous legal systems, including that of Italy, the culture of labour law has also sought to stabilise the said values in positive law by anchoring them to the respective Constitutions. This is the process that has been defined as the "constitutionalisation" of labour law, an eloquent synthesis of which is to be found, for example, in Article 3, Paragraph 2, of the Italian Constitution, which proclaims the principle of substantive equality.

This embodied an attempt to confer upon labour law an almost meta-historic dimension, rendering it impermeable to economic and political changes, in a word to history itself, and ensuring that it could never recede from the levels of protection and citizenship achieved. This was done in the wake of the enlightenment of that time, which created the illusion of a by now inexorable march towards social progress.

${ }^{2}$ For a general overview of the major transformations of labour law systems in the seven decades following the Second World War, see: B. Hepple, B. Veneziani (eds), The Transformation of Labour Law in Europe. A Comparative Study of 15 Countries 1945-2004, Hart Publishing, Oxford 2009.

${ }^{3}$ See S. Deakin, The Many Futures of the Contract of Employment..., p. 195. 


\section{The Employment Contract in the Era of Globalisation}

But that's not the way things went, and the illusions of the golden age of labour law were trampled underfoot. There were indeed numerous factors that, starting with a vengeance in the 90s but with clear harbingers in the 80s too, undermined the foundations on which the "labour law compromise", and hence a certain structure of the employment contract, had been built.

It is common knowledge that the most important of these causal factors (combined with others such as technological transformations and the fragmentation of the job supply) was the vast process of opening of the markets and the mobilisation of capital which started about thirty years ago, and is still now effectively wrapped up by the globalisation label ${ }^{4}$.

In Europe the impact of globalisation was reinforced by the process of monetary unification, which began with the Maastricht Treaty and culminated in 2002 in the adoption of the Euro single currency. The rules and the institutions that presided over this process involved a distinct reduction in the margins of sovereignty of the national States, which could no longer pursue the policies of "deficit spending" and mounting borrowing that had fuelled the previous lengthy phase of economic growth.

In the best-case scenario sufficient financial resources were still available to address situations of social hardship (social shock absorbers and unemployment benefits) but not to foster growth.

Moreover, the productive system, already partially deprived of the State support to which it had become accustomed, could no longer be sustained either by the currency devaluations to which the less competitive countries had regularly resorted prior to the changeover to the Euro.

The entire situation was then further aggravated in the wake of the financial crisis that broke out in 2007-2008, with recession following hard on its heels. As we know, a central component of this phenomenon was the sovereign debt crisis, with possibly the most outstanding example being precisely that of Italy. Similarly well known - although not within the scope of my discussion here ${ }^{5}-$ is the way in which the European Union

${ }^{4}$ See J.D.R. Craig, S.M. Lynk (eds), Globalisation and the Future of Labour Law, Cambridge University Press, Cambridge 2006.

${ }^{5}$ For critical evaluations see N. Counturis, M. Freedland (eds), Resocialising Europe in a time of crisis, Cambridge University Press, Cambridge 2013, and especially C. Crouch, Entrenching neo-liberalism: the current agenda of European social policy, [in:] N. Counturis, M. Freedland (eds), Resocialising Europe..., pp. 36-60; S. Deakin, A. Koukiadaki, The sovereign debt crisis and the evolution of labour law in Europe, [in:] N. Counturis, M. Freedland (eds), Resocialising Europe..., pp. 163-188; A. Supiot, Towards a European policy on work, [in:] N. Counturis, M. Freedland (eds), Resocialising Europe..., pp. 19-35. 
reacted to this crisis, namely through the adoption of stringent austerity policies, deriving from the refusal of the more stable Member States to run the risk of funding the debts of the more exposed countries.

The effect was to further reduce the financial margins at the disposal of the States and the respective economic systems, especially in relation to the weaker economies, which were placed under strict surveillance by the European Union. Thus, if globalisation has triggered a major Darwinian competition at global level, on European scale a second level of competition has been created - and intensified since 2007-2008 - between the countries that are more efficient and stable from a macroeconomic aspect, first and foremost Germany (once it had absorbed the impact of unification), and the others, mostly the so-called peripheral European countries but with even France teetering on the knife-edge, despite enjoying a certain privileged consideration.

Without going into the dramatic case of Greece, an example of this is the influence that the letter sent to Italy from the European Central Bank in August 2011 had in fostering the emergence of the technical government headed by Mario Monti, which was to be characterised by severely restrictive measures on the pensions front and by a distinctly more complex reform of the rules governing the labour market ${ }^{6}$.

Consequently, what has occurred over recent years is effectively a dramatic accentuation of the regulatory trends that had already emerged in the early 90s, when the process of monetary unification was cranked up. In other words, a relative continuity between the changes that took place at the end of the Trente Glorieuses and the current crisis must be recognised ${ }^{7}$.

The effects of the financial shock and then the recession (which has generated a vicious circle with public debt), have, as was inevitable, spread to the labour markets, where the unemployment rate has risen dramatically, mirrored by a drop in the employment rate (partly due to the phenomena of discouragement), albeit to a different degree in the different sectors of the labour market and in the various territorial areas, even within the same country.

The attempts to reboot the growth mechanisms through a substantial modification of European policies have failed to yield positive results to date. And this notwithstanding the fact that the action of the European Central Bank was decisive in defusing tension about the financial markets through the brilliant move of adoption of the OMT programme and other financial mechanisms.

6 The so-called Fornero Reform, adopted through Law, 2012, No 92.

7 For this observation, and more broadly on the current gloomy prospects of labour regulation, see L. Bordogna, La regolazione del lavoro nel capitalismo che cambia: fosche prospettive?, "Stato e mercato" 2012, n. 94, pp. 16-21. 


\section{A Neoliberal Trajectory?}

What has emerged in the new context is like an apparently relentless chain reaction. The loss of shares of national wealth in the sectors most exposed to global competition, added to the cuts in public expenditure, have generated a persistent economic stagnation, recently aggravated by indiscriminate austerity policies. The stagnation has caused a drop in the demand for labour or, at best, the concentration of the demand on flexible jobs, as the enterprise system has sought to react by obsessively demanding flexibility in its various versions, starting with quantitative one. The consequent increase in unemployment and precarious work, affecting young people, women and the elderly in particular, has unleashed a further depressive impact caused by the deriving slump in domestic consumption.

The unemployment question has thus assumed a dramatic centrality, favouring the spread of interpretative models that tend to set the condition of the insiders in opposition to that of the outsiders. These explanations have been sustained primarily by neoliberal thought, nourished by mainstream economics ${ }^{8}$, and channelled through the major economic and financial institutions, but also from sources not traceable to this strand, such as (albeit in a broader perspective) the Supiot Report ${ }^{9}$.

In particular, according to the current neoliberal explanations (on which the standard macroeconomic models are based), the only possible answer to unemployment was liberalisation, that is flexibilisation, of labour markets. This meant that classical labour law was accused of being a causal factor of unemployment.

Of course the assumption that the level of Employment Protection Legislation is causally related to the unemployment rate is far from being generally accepted. It is rather contested not only by the majority of labour lawyers but also by many labour economists. However, this explanation has been explicitly or implicitly accepted by many international and also European institutions, which have always intended, and substantially continue to intend, the "structural" reform of the labour markets mainly as the introduction of more flexibility.

Frequently those who call for reform don't even bother to specify which reforms, it being taken for granted that they necessarily have to move in this direction. So much so that the yardstick for the efficacy of certain measures is not their real impact on the labour markets, but the reduction they have wrought on the OECD EPL index.

${ }^{8}$ In the wake of the model firstly proposed by A. Lindbeck, D.J. Snower, The Insider-Outsider Theory of Employment and Unemployment, MIT Press, Cambridge, Mass. 1984.

9 See the classic A. Supiot, Beyond Employment. Changes in Work and the Future of Labour Law in Europe, Oxford University Press, Oxford 2001. 
In short, European social policies were already trammelled in an increasingly fine neoliberal net even prior to the 2007-2008 crisis $^{10}$.

In effect, starting from the 90 s reforms of a neoliberal stamp were implemented in most of the advanced capitalist countries. They materialised on two concomitant fronts: that of employment regulation and that of the unions.

Under the umbrella of the EPL, policies tending to give considerable scope to the demand for flexibility were adopted. Nevertheless, initially this flexibility was largely discharged not on the standard employment contract but "on the margins" of labour markets, that is on the various atypical or flexible contracts (e.g., fixed-term contracts and temporary work contracts) to which increasing recourse has been made by all the principal systems of labour law ${ }^{11}$.

There was a similar surge in the phenomenon of outsourcing, frequently even to sites beyond the national boundaries, where they were either totally out of reach of labour law (beyond the confines of the EU) or in any case where it had its work cut out to do so (within the European Union area, where the defence of workers employed by enterprises supplying transnational services tends to enter into conflict with the freedom of establishment).

This is not to say that the standard employment relationship was exempt from penetration by flexibility. On the contrary, in terms of certain institutions it was penetrated to a significant degree: take, for example, working hours, which have been rendered extremely flexible almost everywhere, bringing about a profound change in the timeframes within which work is performed.

At the same time, in all the major countries there has been a constant downsizing in the role of the unions and in collective bargaining, which has nevertheless continued to be significant in countries with a more important union tradition, such as Italy.

This latter phenomenon in particular has been the subject of numerous studies of an institutional approach: for example Lucio Baccaro and Chris Howell conducted a survey over a long time span (1974-2005) based on the analysis of the performance of four quantitative indicators in the field of industrial relations (Wage Bargaining Coordination Index, Union Density, Collective Bargaining Centralisation, Conflict Rate) in 15 countries, and also on the qualitative appraisal of several characteristic cases ${ }^{12}$.

${ }^{10}$ See S. Deakin, A. Koukiadaki, The sovereign debt crisis..., p. 164-172.

${ }^{11}$ In Italy, for example, this phase was symbolised by the emanation of the Biagi Decree in 2003, even though the conversion to flexibility had begun in 1996 as a result of the Treu Law.

12 See L. Baccaro, Ch. Howell, A Common Neoliberal Trajectory: the Transformation of Industrial Relations in Advanced Capitalism, "Politics \& Society" 2011, No 39, p. 521-563. 
The conclusion they came to is that in the period under consideration, despite a superficial resilience of the national forms and institutions, in the countries under scrutiny, a general transformation of industrial relations in a neoliberal direction (e.g., with regard to decentralisation of collective bargaining, even in countries with a strong centralised bargaining tradition such as Germany) has taken place, such as to map out a dominant trajectory.

An analysis such as that of Baccaro and Howell ${ }^{13}$ was explicitly proposed as a corrective to the approach based on the Varieties of Capitalism $^{14}$, calling into question the fundamental analytic distinction between Liberal Market Economies and Coordinated Market Economies ${ }^{15}$. This was despite the fact that, as the authors duly observe ${ }^{16}$, the VOC approach was not entirely static even in its original formulation, registering for example that it is much easier to introduce a degree of deregulation into a Coordinated Market Economy than to insert coordination mechanisms into a Liberal Market Economy.

The crisis has further worsened this situation, as it has been clear that - since no other types of adjustment are possible, and signally those of a Keynesian stamp - the labour markets are the only sector of the economy on which the pressure of public opinion to "do something" about unemployment can be discharged ${ }^{17}$.

Truly, in the immediate aftermath of the explosion of the crisis, albeit only for a moment, a crack had actually appeared in the neoliberal certainties. This was caused by the realisation that even relatively unregulated markets, such as that of USA, appeared unable to reboot employment despite a certain upturn in growth, displaying phenomena of "jobless recovery". But then the improvement in these markets swept away even the wavering doubts that had arisen.

${ }^{13}$ It finds confirmation also in W. Streeck, Re-forming Capitalism. Institutional Change in German Political Economy, Oxford University Press, Oxford 2009.

${ }^{14}$ See of course P. Hall, D. Soskice (eds), Varieties of Capitalism. The Institutional Foundations of Comparative Advantage, Oxford University Press, Oxford 2001. For a debate on VOC approach, see B. Hancké (ed.), Debating Varieties of Capitalism, Oxford University Press, Oxford 2009.

${ }^{15}$ On the return of a "common trends" perspective vs. the VOC approach, see M. Regini, Models of Capitalism and the Crisis, "Stato e mercato" 2014, n. 100, pp. 21-44, who stresses the repeated failure of both market and State regulation but in the meantime the great resilience of neoliberal recipes, which is to be explained not only with the dramatic shift of power in favour of the holders of capital, but also with the vanishing of credible actors (such as the unions) that could successfully impose alternative ideas. In general on this crucial topic, see V.A. Schmidt, M. Thatcher (eds), Resilient Liberalism in Europe's Political Economy, Cambridge University Press, Cambridge 2013.

16 See L. Baccaro, Ch. Howell, A Common Neoliberal Trajectory:..., p. 524.

17 See L. Bordogna, La regolazione del lavoro nel capitalismo..., p. 15. 
And so we can say that, while in general, at least in its initial dramatic phase - and in particular in the markets closer to the eye of the storm, such as the financial markets - the crisis brought interventionist policies back into fashion (even though this is not the place to examine whether and how far such regulation was materially implemented), this did not happen for the labour markets, where the approach continued to be dominated by the neoliberal truths.

The flexibilisation of labour law went through a further increase especially in the countries of southern Europe after the outbreak of the 20072008 crisis, with particular regard to the discipline of fixed-term contracts and working time ${ }^{18}$.

In the same countries there was a similar accentuation of the tendency towards decentralisation of collective bargaining ${ }^{19}$ : in Italy Article 8 of Law No 148/2011 established that the collective agreement at plant level can derogate even in peius in certain matters from the law and from the national collective agreements; in Spain Law No 3/2012 formally established the precedence of collective bargaining at plant level over that at national and local level.

From these tidal waves of transformation of increasing intensity there has derived, in general, a reduction of the standards of workers' protection and the redistributive capacity of labour law. And even when the laws have remained formally unaltered, the effectiveness of the discipline has been eroded by union decline ${ }^{20}$.

\section{The Ambivalences of Flexicurity}

The first and easier way in which labour lawyers have tried to hold out against the advance of flexibility was to appeal to the values of labour law and their alleged superiority to economic mechanisms. This entailed a rejection of the "blackmail" of the insider-outsider pattern, underlining the fact that full employment cannot be furthered at the expense of reducing the standards of protection of the workers below a certain level (e.g., giving too much space to temporary contracts).

However this resistance has not succeeded in arresting the incessant advance of flexibility, either politically or culturally.

${ }^{18}$ See S. Deakin, A. Koukiadaki, The sovereign debt crisis..., p. 177-180. For a critical mapping of the national reforms, see S. Clauwert, I. Schomann, The crisis and national labour law reforms: a mapping exercise, Working Paper 2012.04 European Trade Union Institute (Brussels).

19 See S. Deakin, A. Koukiadaki, The sovereign debt crisis..., p. 180-185.

20 See ibidem, p. 172. 
The only realistic way through which European systems could not resign to the neoliberal drift was that of moving the defence line of the European Social Model, but in the meantime accepting the challenge of the adaptation and the modernization of the latter: that is the story of flexicurity.

This was officially adopted by the EU starting from the Green Paper of 2006 and under the aegis of the European Employment Strategy. And it has never since abandoned it, even during the season of crisis, but on the contrary has sought every time to revamp and redefine $i^{21}$. It is remarkable that this was the first time that express solicitations to reform the core of the regulation of labour law had emerged from the European organisms.

However, the flexicurity formula, which can be synthetically understood as a combination of limited job protection, high unemployment benefit levels and active employment policies ${ }^{22}$, has always featured a degree of ambiguity and a possibly manipulative character.

On the one hand, as regards the flexibility aspect, the programme in question pursues two main goals:

a) to acknowledge and render irreversible the acceptance of flexibility, which the systems of labour law have had to metabolise since the 90s in view of the imperative need to make workers' protection compatible with the adaptability of the productive system, and hence with the defence and even the creation of employment;

b) to preach an equable spread of such flexibility to the entire system and not just atypical jobs, so as to ensure that all workers participate in the collective effort to render the labour markets more capable of responding to economic and technological changes and to counter the dualistic tendencies of the labour markets.

On the other hand, to offset the increase and extension of the flexibility, the formula proposes a new concept of security in the labour market, so as to ensure that the worker is economically supported through unemployment benefit when he or she loses a job, and is materially assisted in finding another job through measures of training and professional requalification.

In actual fact, even before flexicurity had come to be specifically spoken of, certain labour lawyers, including the aforementioned Supiot Report and Marco Biagi ${ }^{23}$, had already grasped the fact that there remained

${ }^{21}$ See, for example, EU Council (2009), Flexicurity in times of crisis, European Council Resolution, Luxembourg. On flexicurity in the prospect of Europe 2020, see S. Sciarra, L'Europa e il lavoro. Solidarietà e conflitto in tempi di crisi, Laterza, Roma-Bari 2013, pp. 32-42.

${ }^{22}$ See A. Sanders, The changing face of 'flexicurity' in times of austerity?, [in:] N. Counturis, M. Freedland (eds), Resocialising Europe..., p. 315-316.

${ }^{23}$ See for example M. Biagi, Job Creation and Labour Law: From Protection Towards Pro-Action, [in:] M. Tiraboschi (ed.), Marco Biagi. Selected Writings, Kluwer Law International, The Hague 2003, pp. 105-143. 
little scope for further increases in the levels of protection of employment legislation. They had identified the way forward in a greater protection of the worker outside the employment relationship, that is, in the broader arena of the "external" labour market. So much so, indeed, that Simon Deakin pondering such trends was led to ask himself whether there was any future for the employment contract, even though in the end - considering the evolutionary trend of this institution in the long term - he concluded that it actually had a number of potential futures ${ }^{24}$.

Going even further back, the notion that the worker had to be protected when he/she lost his/her job through both active and passive protection measures (that is, with efficient employment services, first public and then also private), had been sustained and implemented for some time, in a more or less effective way depending on the organisational capacity of such services.

Thus, the manipulative feature of the flexicurity formula resides in the fact that, in order to render greater flexibility acceptable, it proposed a programme of security that was to some extent already comprised in the goals of labour law and welfare law, with the sole novelty that the programme factored in a significant strengthening, apropos the active protection of the worker.

Consequently, even those who like myself have always considered flexicurity as to some extent the inevitable destiny of the European systems of labour law, can understand the scepticism and the criticisms that the formula has aroused among certain labour lawyers ${ }^{25}$.

In my opinion, while acceptable as a fundamental goal, there are certain points to be raised regarding flexicurity which suggest expanding the perspective of labour policy analysis.

In the first place it is incontrovertible that, to date, the emphasis has been more on the flexibility than on the security policies. At this level, the concern to implement efficacious measures to resolve the problems of unemployment, especially among the young, continues to be pivotal. This is regardless of the fact that, incidentally, empirical evidence does not guarantee that it is indeed an effective answer. Every flexibility measure is seen as a point of no return of the system, from which the only way forward is the introduction of more flexibility, and so forth.

Symptomatic, for example, is the recent evolution of the fixed-term contract in Italian experience. The Fornero Reform of 2012 introduced

${ }^{24}$ See S. Deakin, The Many Futures of the Contract of Employment, [in:] J. Conaghan, R.M. Fischl, K. Klare (eds), Labour Law in the Era of Globalization, Oxford University Press, Oxford 2002, p. 194-196.

25 See, for example, those - albeit exaggerated - of A. Supiot, Towards a European policy on work..., p. 27, according to whom flexicurity exemplifies the neoliberal reification of labour. 
for the first time the possibility of drawing up a fixed-term contract for the first-time employment of a worker within the maximum deadline of 12 months, without the need for justification on technical, organisational or productive grounds. A subsequent law of 2013 rendered this contractual form more flexible, establishing that - with the 12-month ceiling remaining in place - two contracts of this type may be entered into with the worker, the second as a continuation of the first. In 2014 the maximum duration of this contract has been extended, through a law promoted by Renzi government, from 12 to 36 months.

Let us then consider the proposal of the "single contract", which is currently under debate in Italy as in other European countries ${ }^{26}$, is - when reduced to essentials - a flexibilisation measure pure and simple. It is being presented as a way of relaunching the open-ended contract but, in actual fact, the condition whereby the employer can freely dismiss the worker during the first three years of this contract, albeit with a reduced economic cost, suggests that this revival of the standard employment contract is really a way of transforming standard employment into flexible employment, involving a long phase of entry into the relationship.

Flexibility also raises further questions. In the first place, in relation to the quantitative flexibility (the one which is more asked by employers), we need to clarify whether an extension of flexibility to standard contracts ought to be offset by restrictions on the abuse of atypical contracts, the adverse effects of which in economic terms have been acknowledged in various quarters ${ }^{27}$.

This is for instance the direction pursued in Italy by the Fornero Reform, which on the one hand alleviated the sanctions for unfair dismissal through the reform of the internationally famous Article 18 of the Workers' Rights Statute, and on the other introduced restrictions and disincentives in relation to certain forms of temporary and atypical work. Nevertheless, it has to be said that this part of the law attracted considerable criticism, largely because it had reduced, in spite of recession, the level of flexibility in temporary contracts.

In the second place, the emphasis on flexibility of a quantitative type appears to be reductive, considering that other aspects of flexibility exist (in terms of tasks, working time and wages) that are no less important and ought to be disciplined.

Finally we come to what is possibly the most important aspect of all: the "flexibility of flexicurity" is deficient in terms of promoting that higher quality labour which is crucial to drive the advanced European econo-

${ }^{26}$ On this topic see G. Casale, A. Perulli, Towards The Single Employment Contract. Comparative Reflections, Hart Publishing, Oxford 2014.

27 See, for example, OECD Employment Outlook (2012). 
mies along the high road of competition ${ }^{28}$, which is in turn the condition for the defence of the European Social Model. Indeed, this can even furnish a challenge to the very notion of flexicurity, given that quality labour tends to assume a relatively permanent or at least not temporary relationship.

Last of all, it goes without saying that the flexibility policies must be shackled to the respect of fundamental social rights ${ }^{29}$, even though the suggestion made by some to build solely upon such rights the rebooting of the programme of labour law seems illusory, given that they identify a minimum threshold level which can be deemed infringed only in the most extreme cases.

Conversely, the efficacy of the security policies was overall considerably lower, except for the countries such as those of northern Europe where these policies were already very strong, and those such as Germany where they have been considerably strengthened.

These difficulties can be traced above all to the fact that, while it is easy to liberalise - since this can be done through measures of a legislative kind that the politicians can present to the media as efficacious interventions approved by international institutions - constructing an effectively operational system of employment services is no easy matter, demanding a considerable organisational commitment in the medium term. And this is also true for programmes of more recent generation, such as the one called "Youth Guarantee" adopted by the European Union in December 2012. In addition to this, the crisis of the welfare systems has prevented the devolution of resources for the enhancement of passive policies.

The difficulties of "market security" are still worse in times of recession such as that we are currently going through, in which support for the unemployed is rendered critical by the lack of public funds, and the drop in the demand for labour makes the transition from one job to another much more difficult ${ }^{30}$. Hence the suggestion that at European level we should return to developing the old-fashioned concept of "job security", possibly with the trade-off of greater internal flexibility ${ }^{31}$.

Anyway it must not be forgotten that there is no model valid for all countries and that flexicurity is simply a general guideline. It is well known that - alongside the pure model of flexicurity, generally identified

${ }^{28}$ See B. Gazier, La Strategia europea per l'occupazione nella tempesta: il ripristino di una prospettiva a lungo termine, "Diritto delle relazioni industriali" 2011, n. 1, p. 71.

${ }^{29}$ On which see, for example, N. Counturis, M. Freedland, Epilogue: resocialising Europe..., p. 495-503.

30 See A. Sanders, The changing face of 'flexicurity..., p. 318-319.

31 See M. Weiss, Job security: a challenge for EU social policy, [in:] N. Counturis, M. Freedland (eds), Resocialising Europe in a time of crisis, Cambridge University Press, Cambridge 2013, p. 278-279. See also N. Counturis, M. Freedland, Epilogue: resocialising Europe..., p. $497-498$. 
with that of Denmark, which trusts totally on the efficiency of its own employment services, there are also more spurious forms such as that of Germany which, while being open to flexible jobs to a certain degree, has not dismantled the protection against unfair dismissal. With particular regard to those cases, the empirical evidence shows that the countries characterised by pure flexicurity policies have experienced higher rises in unemployment as a result of the crisis than the continental group ${ }^{32}$.

To round off, the prospect of flexicurity evokes many uncertainties, and it is not clear whether it can represent an efficacious alternative to the neoliberal approach adopted by a certain dominant way of thought, particularly of an economic imprint.

Despite this, flexicurity appears to be an obligatory marching route, which nevertheless must be placed within a broader and more sophisticated range of labour policies, aimed at the promotion of permanent, quality employment ${ }^{33}$ and the adoption of more efficacious security mechanisms.

\section{Conclusions}

There are still dark clouds looming in the sky of labour law. Left to their own devices, the European systems of labour law continue to be subject to laborious adaptations and corrections in the search for ways to counteract the priority problem of unemployment.

A more efficacious policy action on the part of the European organisms, aimed at directing the national policies along virtuous paths, is definitely called for, but it comes up against the current stalemate in the process of European integration, which as things stand at present relegates the conclusion of a Social Compact to a hope for the future ${ }^{34}$. Nor ought we to overlook the weighty conditioning of social policies exercised upstream by the austerity policies that are still being adopted by the European Union ${ }^{35}$.

In the meantime there is much work to be done to reconceive the foundations and the methods of the discipline. If we don't want to resign ourselves to the "race to the bottom" of labour protection in the name of a flexibility subject to continual raising of the stakes, which is a possible

${ }^{32}$ See P. Auer, La flexicurity nel tempo di crisi, "Diritto delle relazioni industriali" 2011, n. 1, p. 49.

${ }^{33}$ See T. Treu, Le istituzioni del lavoro nell'Europa della crisi, "Diritti sociali del lavoro" 2013, n. 140, p. 613.

${ }^{34}$ See the realistic albeit still cautiously optimistic approach of T. Treu, Le istituzioni del lavoro..., p. 631-633.

${ }^{35}$ For various criticisms, see S. Deakin, A. Koukiadaki, The sovereign debt crisis..., p. 185-188; A. Supiot, Towards a European policy on work..., p. 33-34. 
scenario, we also need to start thinking - as indeed numerous labour lawyers have been doing for some time ${ }^{36}$ - about the aims and the techniques of labour law.

For example, Guy Davidov has argued for the expediency of a new articulation of labour law's goals and means, through a complex analysis whose passages cannot be followed here ${ }^{37}$. I would add to his persuasive arguments that this renewal ought to pivot on attributing greater importance to the empirical and practical dimensions, rather than the strictly normative, also so as to be able to make a more informed appraisal of the real impact of legislative measures.

Which in its turn assumes that, contrary to tradition, the epistemological knowledge of the labour lawyer must be extremely open to exchange with other social sciences, naturally starting with economics.

It is pointless to conceive of labour law as opposed to economics, as if the former could still concern itself merely with the distribution of wealth and not also - especially at a time of low growth - with its production. Labour law should be law that fuses value claims and organisational and economic considerations. That also in the light of the fact, evidence of which is widely accepted, that many rules of labour law can have an impact on efficiency ${ }^{38}$.

Finally, such a progress could also be fostered by a theoretical updating of the protective paradigm, based on the passage from a concept of paternalistic protection to one that is positive and proactive, concentrated on the effective needs of the workers seen as individuals (given the apparently relentless decline of the collective dimension) and that is capable of mobilising their autonomy and responsibility. The new labour law should be constructed solely with the active engagement of the workers, and hence no longer considering them merely as weak subjects to be protected.

In a recent $\operatorname{article}^{39} \mathrm{I}$ argued (although this same opinion has also been sustained by several influential scholars ${ }^{40}$ ) that this update could draw

${ }^{36}$ See especially G. Davidov, B. Langille (eds), The Idea of Labour Law, Oxford University Press, Oxford 2011.

37 See G. Davidov, Re-Matching Labour Laws with Their Purpose, [in:] G. Davidov, B. Langille (eds), The Idea of Labour Law, Oxford University Press, Oxford 2011, p. 179-189; The Goals of Regulating Work: Between Universalism and Selectivity, www.labourlawresearch. net (2012).

${ }^{38}$ See S. Deakin, A. Koukiadaki, The sovereign debt crisis..., p. 169.

39 See R. Del Punta, Leggendo "The Idea of Justice", di Amartya Sen, "Diritto del lavoro e di relazioni industriali" 2013, n. 138, p. 197-220.

40 See especially B. Langille, Labour Law's Theory of Justice, [in:] G. Davidov, B. Langille (eds), The Idea of Labour Law..., p. 101-119; S. Deakin, The Contribution of Labour Law to Economic and Human Development, [in:] G. Davidov, B. Langille (eds), The Idea of Labour Law..., p. 156-178. See also S. Deakin and A. Supiot, Capacitas. Contract Law and the Institutional Preconditions of a Market Economy, Hart Publishing, Oxford-Portland 2009. 
benefit from a comparison with Amartya Sen's Capability Approach ${ }^{41}$, which is generating much interdisciplinary research ${ }^{42}$ and can be potentially important for labour law both as a normative political theory and as a method of economic and social analysis.

Restricting myself to just a few hints, the Capability Approach could be an ideal yardstick for flexicurity policies, on the one hand with regard to the dimension of flexibility within the employment contract, since the concept of capability can factor in the need for a power equilibrium between parties $^{43}$ (which the economists instead ignore and/or neglect) and hence counteract the tendency to flexibilise every aspect of the employment relationship, while at the same time going beyond the old "inequality of power" narrative; and on the other hand in relation to strengthening the worker's position in the labour market, in line with the aforementioned concept of "work (rather than job) security" 44 . But this is only one of the many possible paths in the complex quest for that new thinking that alone can point the way to a modernisation of the discipline capable of evoking a hope for the future of labour in the advanced economies as well in the countries that are experiencing maximum economic development.

Depending on the success of this quest, what now plausibly appears as a structural decline, due to the disruptive effects of neoliberal global 136 trends, could be transformed into a medium-term regeneration. Moreover, even if the most optimistic scenario should materialise, it will not happen without elevated difficulties and costs: as Marco Biagi, who was so fond of this word, was well aware, "every process of modernisation takes place through travail, and also through social tension, in short paying a high price to conflict" (from the last article by Marco Biagi, Il Sole 24 ore, 21 March 2002).

\section{Bibliography}

Auer P., La flexicurity nel tempo di crisi, "Diritto delle relazioni industriali" 2011, n. 1, p. 49. Baccaro L., Howell Ch., A Common Neoliberal Trajectory: the Transformation of Industrial Relations in Advanced Capitalism, "Politics \& Society" 2011, No 39, pp. 521-563.

${ }^{41}$ See, ex multis, A.K. Sen, Development as Freedom, Oxford University Press, Oxford 1999; idem, The Idea of Justice, Penguin Group, London 2009.

${ }^{42}$ See, for instance, F. Comim, M. Qizilbash, S. Akire (eds), The Capability Approach. Concepts, Measures and Applications, Cambridge University Press, Cambridge 2008.

${ }^{43}$ On the delicate conceptual intersection between capability and power, see A. Sen, The Idea..., p. 304-306, who himself suggests that his theory can be (not replaced by, but) integrated through the concept of liberty as non-domination, proposed by P. Pettit (see recently P. Pettit, Just Freedom. A Moral Compass for a Complex World, W. W. Norton \& Company, New York-London 2014).

${ }^{44}$ See B. Gazier, La Strategia europea per l'occupazione nella tempesta..., p. 70. 
Biagi M., Job Creation and Labour Law: From Protection Towards Pro-Action, [in:] M. Tiraboschi (ed.), Marco Biagi. Selected Writings, Kluwer Law International, The Hague 2003, pp. 105-143.

Bordogna L., La regolazione del lavoro nel capitalismo che cambia: fosche prospettive?, "Stato e mercato" 2012, n. 94, pp. 16-21.

Casale G., Perulli A., Towards The Single Employment Contract. Comparative Reflections, Hart Publishing, Oxford 2014.

Clauwaert S., Schömann I., The crisis and national labour law reforms: a mapping exercise, Working Paper 2012.04 European Trade Union Institute (Brussels).

Comim F., Qizilbash M., Akire S. (eds), The Capability Approach. Concepts, Measures and Applications, Cambridge University Press, Cambridge 2008.

Counturis N., Freedland M., Epilogue: resocialising Europe - looking back and thinking forward, [in:] N. Counturis, M. Freedland (eds), Resocialising Europe in a time of crisis, Cambridge University Press, Cambridge 2013, pp. 495-503.

Craig J.D.R., Lynk S.M. (eds), Globalisation and the Future of Labour Law, Cambridge University Press, Cambridge 2006.

Crouch C., Entrenching neo-liberalism: the current agenda of European social policy, [in:] N. Counturis, M. Freedland (eds), Resocialising Europe in a time of crisis, Cambridge University Press, Cambridge 2013, pp. 36-60.

Davidov G., Re-Matching Labour Laws with Their Purpose, [in:] G. Davidov, B. Langille (eds), The Idea of Labour Law, Oxford University Press, Oxford 2011, pp. 179-189.

Davidov G., The Goals of Regulating Work: Between Universalism and Selectivity, www.labourlawresearch.net (2012).

Davidov G., Langille B. (eds), The Idea of Labour Law, Oxford University Press, Oxford 2011.

Deakin S., The Contribution of Labour Law to Economic and Human Development, [in:] G. Davidov, B. Langille (eds), The Idea of Labour Law, Oxford University Press, Oxford 2011, pp. $156-178$.

Deakin S., The Many Futures of the Contract of Employment, [in:] J. Conaghan, R.M. Fischl, K. Klare (eds), Labour Law in the Era of Globalization, Oxford University Press, Oxford 2002, p. 194-195.

Deakin S., Koukiadaki A., The sovereign debt crisis and the evolution of labour law in Europe, [in:] N. Counturis, M. Freedland (eds), Resocialising Europe in a time of crisis, Cambridge University Press, Cambridge 2013, pp. 163-188.

Deakin S., Supiot A., Capacitas. Contract Law and the Institutional Preconditions of a Market Economy, Oxford-Portland: Hart Publishing (2009)

Del Punta R., Leggendo "The Idea of Justice", di Amartya Sen, "Diritto del lavoro e di relazioni industriali" 2013, n. 138, pp. 197-220.

EU Council, Flexicurity in times of crisis, European Council Resolution, Luxembourg (2009)

Gazier B., La Strategia europea per l'occupazione nella tempesta: il ripristino di una prospettiva a lungo termine, "Diritto delle relazioni industriali" 2011, n. 1.

Hall P., Soskice D. (eds), Varieties of Capitalism. The Institutional Foundations of Comparative Advantage, Oxford University Press, Oxford 2001.

Hancké B. (ed.), Debating Varieties of Capitalism, Oxford University Press, Oxford 2009.

Hepple B., Veneziani B. (eds), The Transformation of Labour Law in Europe. A Comparative Study of 15 Countries 1945-2004, Hart Publishing, Oxford 2009.

Langille B., Labour Law's Theory of Justice, [in:] G. Davidov, B. Langille (eds), The Idea of Labour Law, Oxford University Press, Oxford 2011, pp. 101-119.

Lindbeck A., Snower D.J., The Insider-Outsider Theory of Employment and Unemployment, MIT Press, Cambridge, Mass. 1984. 
OECD Employment Outlook (2012)

Pettit P., Just Freedom. A Moral Compass for a Complex World, W. W. Norton \& Company, New York-London 2014.

Regini M., Models of Capitalism and the Crisis, "Stato e mercato" 2014, n. 100, pp. 21-44.

Sanders A., The changing face of 'flexicurity' in times of austerity?, [in:] N. Counturis, M. Freedland (eds), Resocialising Europe in a time of crisis, Cambridge University Press, Cambridge 2013, pp. 315-316.

Schmidt V.A., Thatcher M. (eds), Resilient Liberalism in Europe's Political Economy, Cambridge University Press, Cambridge 2013.

Sciarra S., L'Europa e il lavoro. Solidarietà e conflitto in tempi di crisi, Laterza, Roma-Bari 2013, pp. 32-42.

Sen A.K., Development as Freedom, Oxford University Press, Oxford 1999.

Sen A.K., The Idea of Justice, Penguin Group, London 2009.

Streeck W., Re-forming Capitalism. Institutional Change in German Political Economy, Oxford University Press, Oxford 2009.

Supiot A., Beyond Employment. Changes in Work and the Future of Labour Law in Europe, Oxford: Oxford University Press (2001)

Supiot A., Towards a European policy on work, [in:] N. Counturis, M. Freedland (eds), Resocialising Europe in a time of crisis, Cambridge University Press, Cambridge 2013, pp. 19-35.

Treu T., Le istituzioni del lavoro nell'Europa della crisi, "Diritti sociali del lavorno" 2013, n. 140, p. 613

Weiss M., Job security: a challenge for EU social policy, [in:] N. Counturis, M. Freedland (eds), Resocialising Europe in a time of crisis, Cambridge University Press, Cambridge 2013, p. 278-279.

\section{Prawo pracy na skraju: neoliberalny upadek, czy odrodzenie?}

\section{Streszczenie}

Rozdział ten dotyczy procesów, które głęboko zmieniły prawo pracy w erze globalizacji i które, jak się wydaje, będą kontynuowane w bliskiej przyszłości, rodząc niepewność co do przyszłości umowy o pracę.

Cechy umowy o pracę w jej tradycyjnej postaci, która ukształtowała się w chwalebnych latach rozwoju prawa pracy, zostały po raz pierwszy podważone. Przedmiotem niniejszych rozważań są czynniki, które doprowadziły do upadku tej konstrukcji, wyzwalając proces złożonych i niepewnych zmian.

Zgodnie z pierwszym schematem interpretacyjnym, niezależnie od różnic indywidualnych kontekstów instytucjonalnych, ewolucja systemów prawa pracy nastąpiła w nurcie przewagi orientacji neoliberalnej, powodującej podważenie podstaw Europejskiego Modelu Socjalnego.

W odróżnieniu od tego, według drugiego schematu interpretacji, Europejski Model Socjalny został po prostu dostosowany, pod nazwą "flexicurity”, jakkolwiek podkreślić należy istnienie wielu niepewności związanych z tą koncepcją i polityką.

W konkluzji autor wskazuje, że samo flexicurity nie może być satysfakcjonująca perspektywą dla prawa pracy, stojącego wobec ogólnoświatowego ataku i że należy podjąć dalszą teoretyczną pracę w celu włączenia flexicurity w szerszą perspektywę cechującą się odnową fundamentów tej dyscypliny prawa. 